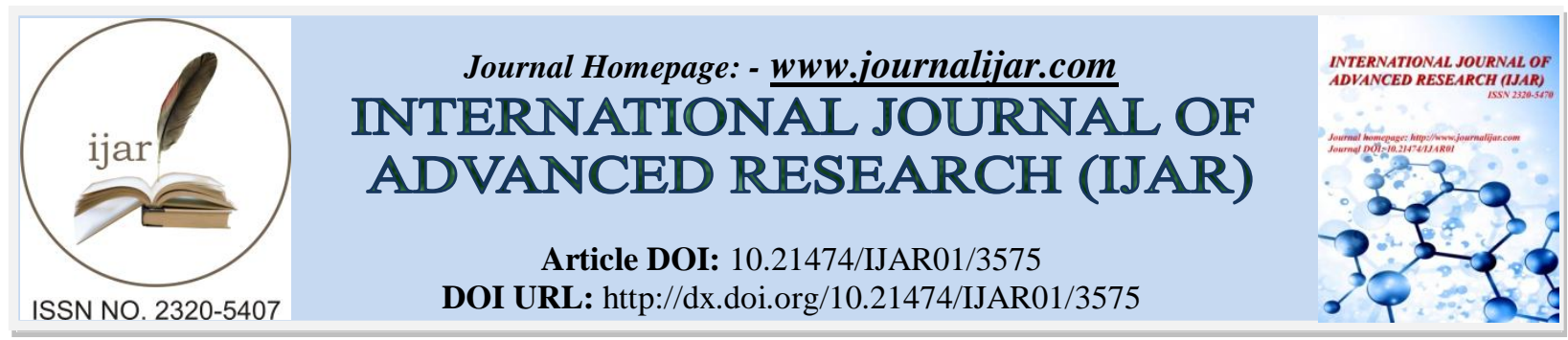

RESEARCH ARTICLE

\title{
A STUDY ON RELATIONSHIP BETWEEN ERP IMPLEMENTATION AND MANAGEMENT ACCOUNTING PRACTICES.
}

\author{
Dhaarna Singh Rathore ${ }^{1}$ and Dr. Heena S. Oza ${ }^{2}$.
}

1. Assistant Professor, Auro University, Surat. Contact: 7621904363.

2. Associate Professor, S.P.B. English Medium college, Surat.

\section{Manuscript Info}

Manuscript History

Received: 03 January 2017

Final Accepted: 10 February 2017

Published: March 2017

Key words:-

Implementations, SME's, Accounting.

\begin{abstract}
With ever changing global scenario in business sector, uses of ERP (Enterprise resource Planning) to cut down on accounting cost have gained a rapid growth. Not only large enterprises, but medium as well as small enterprises have gone on the path of ERP implementations. Using an ERP in your accounting, not only cuts down the time consumption in maintaining accounting records, but also helps in managerial accounting and decision making with ready to use real time data on click of a button. This paper has been analyzed on impact of ERP implementations on the management accounting process on different kinds of industries. Previous study talks about many references to factors underlining successful ERP implementations with reference to plummeting management accounting decision making burden. Multiple regression analysis has been done on the basis of factors and methods of management accounting extracted from review of literature. The focus of this paper is to give a scenario for further research with respect to impact on management accounting as a result of ERP implementations.
\end{abstract}

Copy Right, IJAR, 2017,. All rights reserved.

\section{Introduction:-}

With the rapid advancement of ERP systems in LE's and SME's the management has got sheer benefits of quick decision making process with the help of readily available data on click of a button. But does implementation of an ERP into a company's environment actually affects the process of Management Accounting.

ERP is a planning philosophy enabled with software that attempts to integrate all the business processes of all the departments and functions across a company on to a single computer system that can serve particular needs of the different departments. ERP combines all the business requirements of the company into a single, integrated software program that runs of a single database so that the various departments can more easily share information and communicate with each other. Fig.1 shows ERP integrated system. (Altekar, 2009)

Corresponding Author:- Dhaarna Singh Rathore.

Address:- Assistant Professor, Auro University, Surat. Contact: 7621904363. 


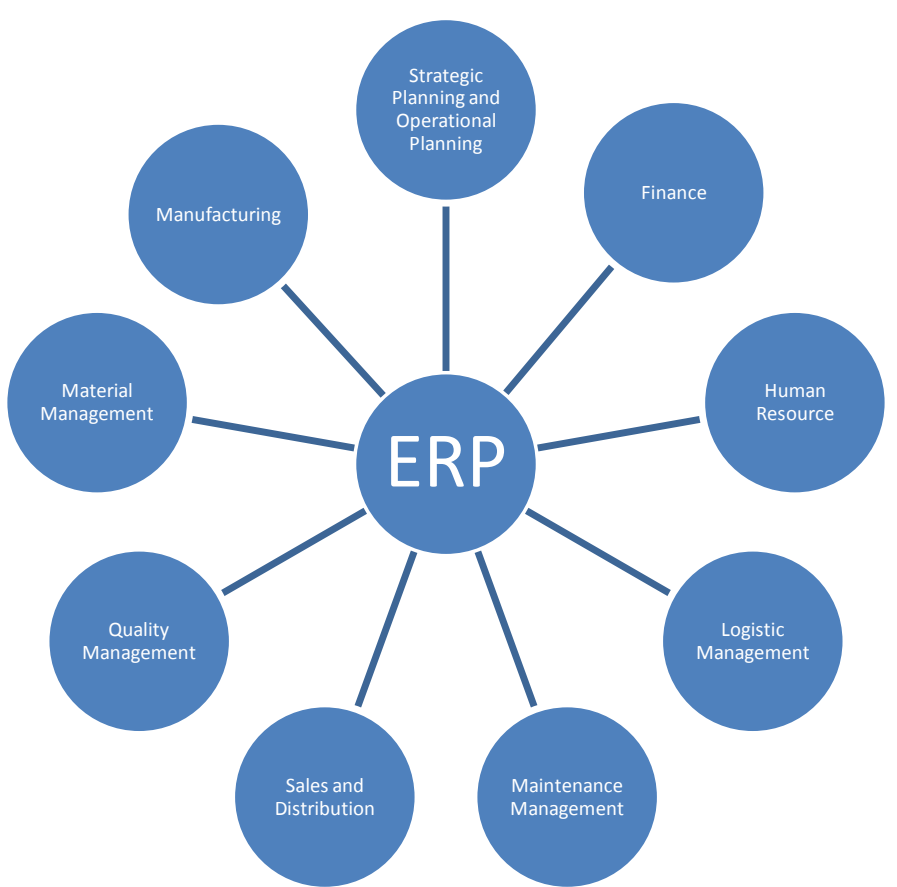

Figure 1:- ERP Integrated Systems.

Management Accounting is a process of identifying, measuring, analyzing, interpreting and communicating information in pursuit of an organization's goals. Management accounting is an integral part of management process, and managerial accountants are important strategic partners in the organization's management team. In pursuing its goals, an organization acquires resources, hires people and then engages in an organized set of activities. It is up to management team to make the best use of organizations resources, activities and people in achieving the organization's goals. The management accounting has four activities involved:

\section{Decision Making}

\section{Planning}

\section{Directing opertaional activities}

\section{Controlling}

Figure 2:- (Ronald W Hilton, 2008) 


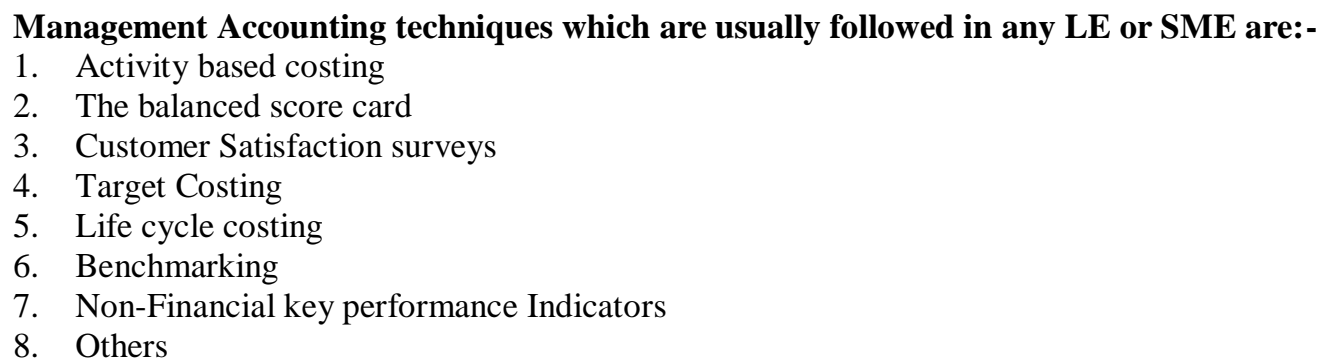

The combination of ERP and Management accounting does brings changes in a company's day to day activities. Management accounting relies on combined data of all the departments combined together to attain a common decision making goal. With the help of ERP this can be done easily as the data is readily available. Now the hypothesis arise as to whether implementing an ERP can be beneficial to a company or it can bring heavy costs in implementation as compared to easy data availability to the management.

\section{Objective of Research and Hypothesis:-}

The research has been done with an objective of analyzing the post ERP implementation effect of management accounting processes. The major objectives of research are listed below:

1. To find out the impact of ERP implementation on the organizations overall management accounting process.

2. To find whether management accounting processes are related to size of organization in an ERP environment.

3. To find the impact of Management processes on different factors of better performance in an ERP environment.

The hypothesis of research is as follows:

. Objective 1:- Hypothesis

$\mathrm{Ha}_{0}$ : ERP implementation has a positive impact on management accounting Processes.

$\mathrm{Ha}_{1}$ : ERP implementation does not bring a positive impact on management accounting processes.

\section{Objective 2:- Hypothesis}

$\mathrm{Hb}_{0}$ : To find whether management accounting processes are related to size of organization in an ERP environment.

$\mathrm{Hb}_{1}$ : There is no relation between management accounting processes to size of organization in an ERP environment.

\section{Objective 3:- Hypothesis}

$\mathrm{Hc}_{0}$ : All management process has similar impact in an ERP environment

$\mathrm{Hc}_{1}$ : All management process has different impact in an ERP environment.

\section{Review Of Literature:-}

The deployment of ERP systems generally results in significant reductions in the routine tasks of management accountants [ (Lowe, 2004); (Arnold, 2006); (Drury, 2008)] and the subsequent a transition in their role from one of information gatherer or transaction-orientated role, to one of information analyst or business orientated role [ (Granlund M. a., 1998); Hunton, 2002] or more simply from the back office to the front office (Holtzman, 2004). Furthermore, management accounting practices, whether traditional or modern, may become more efficient and effective when supported with ERP systems (see, for example, Edwards, 2001; Baxendale and Jama, 2003; Lea and Min, 2003; Scapens and Jazayeri, 2003; He, 2007; Lea, 2007). This is possible through greater information integration, greater flexibility in information access, and superior functionality (Booth et al., 2000). More recently, the enrichment of ERP systems with new ES, such as business intelligence BI) systems, appears to have had a significant boost to the role of management accounting. BI systems normally sit on top of ERP systems, and are intended to bridge transactional efficiency with strategic planning. BI comprise a set of tools used for data analysis, query and reporting (Elbashir et al., 2008) and supporting strategic decision-making (Fahy, 2001; Bucher et al., 2009; Mikroyannidis and Theodoulidis, 2010) by providing managers with insights into their business operations (Seah et al., 2010). BI systems are composed of three complementary and interrelated tools, namely data warehousing, online analytical processing (OLAP), and data mining. As Teorey et al. (2006) describe, data warehousing deals with the storage, maintenance and retrieval of historical data; OLAP provides quick answers to ad hoc queries; and data mining is a collection of algorithms which find patterns in the data and return valuable user information. (Nikolaos Vakalfotis, July 2011) 
(Gullkvist, Sept, 2013) Says empirical findings demonstrate a statistically significant influence of a successful ERP implementation as having a direct effect on changes in MA practices. While Sangster et al. (2009) identified increased data quality, improved decision-making and changes in accountants tasks under successful ERP implementations, this study adds to those findings by emphasizing change in MA techniques as associated with successful ERP implementation. Consistent with reasoning in prior research (Granlund and Malmi, 2002), the results of this study indicate that time since ERP adoption is a significant determinant of changes in MA techniques, but also that the majority of the changes occur within eight years after ERP implementation. Further, late ERP adopters perceive greater changes in MA techniques than early adopters. One possible explanation could be that late adopters perceive the changes as greater because of the short time since ERP implementation. Another explanation could be that newer software versions include features and functionality that were missing from their predecessors, and which could be driving the changes already at the ERP implementation stage. Some respondents maintained in an open question in the questionnaire that change in MA techniques occurred simultaneously with the ERP implementation, not afterwards. Furthermore, the findings indicate that the scope of installation, local or global, is a significant determinant of changes in MA techniques. This is an important finding, as many organizations in recent years have pursued global ERP implementation. As many previous studies on the attributes of MA change have been conducted at an early stage of ERP implementation and early in the first decade of the century, this study offers an update, and also indicates that change may occur over time.

Where (Hyvonen, 2003) gave a comparison of ERP: Enterprise Resource Planning and BoB: Best of breed with respect to management accounting systems. He collected data through 300 postal questionnaires from large and middle sized industrial units in Finland. The questionnaire addressed questions concerning IS implementation (why. how and by what the IS project was introduced), management accounting function, and the use of advanced management accounting techniques. The results obtained indicate that financial departments have been more interested in traditional BoB systems, while other departments have concentrated more on ERP solutions. Further, as the articulated motives behind the IS project were strategic, and moreover technical in nature, the solution in most cases was ERP, while in the cases where motives were either strategic or technical, the choice was BoB. Otherwise, there were no statistically significant differences between the groups of BoB or ERP adopters, and the problems perceived in management accounting or the adoption of advanced management accounting techniques (e.g. ABC, $\mathrm{ABM}$ and $\mathrm{BSC})$.

Two seminal studies are (Granlund M. a., 2002) and (Scapens, 2003)S. Granlund and Malmi (2002) undertook exploratory field studies at ten firms. They recognized that ERP systems provided easier and faster access to standardized operational data, enhanced forecasting, emphasized the accounting department as the "nerve center", reduced the need for accountants to handle routine tasks, and gave accountants more time for sophisticated analyses. Nevertheless, they concluded ( Granlund and Malmi, 2002, p. 309) "that there has been no major direct or indirect impact so far on management accounting and management control systems". Granlund and Malmi (2002) appear to be assessing the impact of ERP systems on management accounting from the third or information level, rather than the physical and transactional levels, in recognizing the greater ease and speed in accessing standardized data and in recognizing that the work of management accountants had shifted towards more analysis and fewer routine tasks. In recognizing better information, they did not mention that significant changes to transaction processing were necessary for better information. Moreover, they did not mention the standardization of the state-of-the-art physical processes that were necessary to support improved transaction processing.

(Rohde, 2006) Had done a paper to contribute to the body of knowledge about to what extent integrated information systems, such as ERP and SEM systems, affect the ability to solve different management accounting tasks. They made a questionnaire survey with 349 responses and data so collected was analyzed using linear regression models. Analyses indicate that ERP systems support the data collection and the organizational breadth of management accounting better than SEM systems. SEM systems, on the other hand, seem to be better at supporting reporting and analysis. In addition, modern management accounting techniques involving the use of non-financial data are better supported by an SEM system. This indicates that different management accounting tasks are supported by different parts of the IIS. On the basis of the findings, there is a need to consider the potential of closer integration of ERP and SEM systems in order to solve management accounting tasks.

(Sánchez-Rodríguez \& Spraakman, 2012) Studied eight international scientific journals published between 1990 and 2010 to relationship between ERP and Management Accounting. They found on the basis of conceptual study that 
not much work has been done in ERP and MA as such. They also concluded that SAP has a major role when it comes to ERP in Management Accounting decision making. They recommended area for further research in this field as not much work has been done on following:

- What are the critical context factors for implementation of ERP system?

- Analysis and interaction between ERP and organizational structure.

- Impact of ERP on management accounting and management accountant.

- The integration of BI, Cloud computing and ERP.

(Malinic \& Todorovic, 2012) Talks about the effect of SAP on management accounting in Serbian industrial enterprises. They studied 9 enterprises from different industry to explore the relationship between SAP, as only one of the ERP software and management accounting changes. They concluded the impact of SAP on MA is modest in relation to expectation "Granlund and Malmi (2002)". Also they concluded that there is no causal relationship between ERP implementation and management accounting procedures. They suggested certain remarkable points to be considered while comparing MA and ERP:

- SAP implementation is complex at initial stage.

- SAP implementation is time consuming and it takes a lot of time to implement in all the sectors of the organizations.

- Time gap between implementation and go live is another important factor which influences the decision.

- Wrong decision in ERP tie-ups are also a reason of failure.

- SAP brings in time effectiveness in managerial decision making.

Again (Sangster, Leech, \& Grabski, 2009) also found out by floating 700 questionnaires in different IT professionals that SAP was the dominate vendor of ERP implementations. On the basis of their research it has been identified that ERP implementations results in changes in the tasks of the management accountants, with the quality of many operational factors, such as inventory control, and the overall quality of data and information improving irrespective of the success or failure of the implementation. When an ERP implementation is successful, management accountants have time for other, less mundane activities; and their role becomes more enriching as a result.

Table 1:- Table showing Comparison of factors for performance measure of ERP and Management Accounting Relationship

\begin{tabular}{|c|c|c|c|c|c|c|c|c|c|c|}
\hline Authors & $\begin{array}{l}\text { (Gaertn } \\
\text { er \& } \\
\text { Feldba } \\
\text { uer- } \\
\text { Durstm } \\
\text { ueller, } \\
2012)\end{array}$ & $\begin{array}{l}\text { Hyv } \\
\text { onen } \\
(200 \\
3\end{array}$ & $\begin{array}{l}\text { (Mali } \\
\text { nic \& } \\
\text { Todor } \\
\text { ovic, } \\
2012 \text { ) }\end{array}$ & $\begin{array}{l}\text { (San } \\
\text { gster, } \\
\text { Leec } \\
\text { h, \& } \\
\text { Grab } \\
\text { ski, } \\
2009 \\
\text { ) }\end{array}$ & $\begin{array}{l}\text { (San } \\
\text { gster, } \\
\text { Leec } \\
\text { h, \& } \\
\text { Grab } \\
\text { ski, } \\
2009 \\
\text { ) }\end{array}$ & $\begin{array}{l}\text { (Mali } \\
\text { nic \& } \\
\text { Todor } \\
\text { ovic, } \\
2012)\end{array}$ & $\begin{array}{l}\text { (Niko } \\
\text { laos } \\
\text { Vakal } \\
\text { fotis, } \\
\text { July } \\
2011 \text { ) }\end{array}$ & $\begin{array}{l}\text { (Gull } \\
\text { kvist, } \\
\text { Sept, } \\
\text { 2013) }\end{array}$ & $\begin{array}{l}\text { (Ro } \\
\text { hde, } \\
200 \\
6)\end{array}$ & $\begin{array}{l}\text { Sum } \\
\text { mary }\end{array}$ \\
\hline \multicolumn{11}{|l|}{ Factors } \\
\hline corporate size & GS & & GS & GS & & & & & & LS \\
\hline corporate strategy, & GS & GS & & & GS & & LS & & & LS \\
\hline Organizational Structure & GS & & GS & GS & GS & GS & GS & & GS & GS \\
\hline $\begin{array}{l}\text { Management Accounting \& } \\
\text { Management Accountants }\end{array}$ & GS & GS & GS & & GS & GS & GS & GS & GS & GS \\
\hline $\begin{array}{lll}\begin{array}{l}\text { Integration } \\
\text { intelligence }\end{array} & \text { of } & \text { business } \\
\end{array}$ & GS & GS & GS & GS & GS & GS & GS & GS & GS & GS \\
\hline Cloud Computing & LS & & & & & & & & & LS \\
\hline Perfromance Measurement & LS & GS & GS & GS & GS & GS & & & & GS \\
\hline Cost Accounting & LS & GS & & & & GS & GS & & GS & GS \\
\hline Data Analysis & LS & GS & & GS & & GS & GS & GS & GS & GS \\
\hline Reporting & GS & GS & & GS & & GS & & & GS & GS \\
\hline Budgeting & LS & GS & GS & GS & & GS & GS & & GS & GS \\
\hline
\end{tabular}


Note:-

GS= Good Support for inclusion as a performance measures in ERP and Management Accounting Relationship. (Performance measure referenced in $50 \%$ or more of studies in the table).

$\mathbf{L S}=$ Low support for inclusion as a performance measures in ERP and Management Accounting Relationship. (Performance measure referenced in less than $50 \%$ of studies in the table).

Table 2:- Table Showing Methods of Management Accounting Implemented / Accepted in studies under review

\begin{tabular}{|c|c|c|c|c|c|c|c|c|c|c|}
\hline Authors & $\begin{array}{l}\text { (Gaertner } \\
\& \\
\text { Feldbaue } \\
\text { r- } \\
\text { Durstmu } \\
\text { eller, } \\
2012)\end{array}$ & $\begin{array}{l}\text { Hyvo } \\
\text { nen } \\
(2003\end{array}$ & $\begin{array}{l}\text { (Malini } \\
\text { c \& } \\
\text { Todoro } \\
\text { vic, } \\
\text { 2012) }\end{array}$ & $\begin{array}{l}\text { (Sangs } \\
\text { ter, } \\
\text { Leech, } \\
\& \\
\text { Grabs } \\
\text { ki, } \\
\text { 2009) }\end{array}$ & $\begin{array}{l}\text { (Sangs } \\
\text { ter, } \\
\text { Leech, } \\
\& \\
\text { Grabs } \\
\text { ki, } \\
\text { 2009) }\end{array}$ & $\begin{array}{l}\text { (Malini } \\
\text { c \& } \\
\text { Todoro } \\
\text { vic, } \\
\text { 2012) }\end{array}$ & $\begin{array}{l}\text { (Nikola } \\
\text { os } \\
\text { Vakalf } \\
\text { otis, } \\
\text { July } \\
2011 \text { ) }\end{array}$ & $\begin{array}{l}\text { (Gullk } \\
\text { vist, } \\
\text { Sept, } \\
2013 \text { ) }\end{array}$ & $\begin{array}{l}\text { Roh } \\
\text { de, } \\
2006 \\
\text { ) }\end{array}$ & $\begin{array}{l}\text { Summ } \\
\text { ary }\end{array}$ \\
\hline \multicolumn{11}{|l|}{ Methods } \\
\hline $\begin{array}{l}\text { Activity Based } \\
\text { Costing }\end{array}$ & GS & GS & GS & $\mathrm{LS}$ & GS & GS & $\mathrm{LS}$ & GS & GS & GS \\
\hline $\begin{array}{l}\text { Balance Score } \\
\text { Card }\end{array}$ & GS & GS & LS & LS & GS & GS & $\mathrm{LS}$ & GS & GS & GS \\
\hline Target Costing & GS & GS & LS & LS & GS & GS & LS & GS & GS & GS \\
\hline $\begin{array}{l}\text { Lifecycle } \\
\text { Costing }\end{array}$ & GS & GS & LS & LS & GS & GS & LS & GS & GS & GS \\
\hline
\end{tabular}

Note:-

GS= Good Support for inclusion as a performance measures in ERP and Management Accounting Relationship. (Performance measure referenced in $50 \%$ or more of studies in the table).

$\mathbf{L S}=$ Low support for inclusion as a performance measures in ERP and Management Accounting Relationship. (Performance measure referenced in less than $50 \%$ of studies in the table).

Based on the review of literature it can be ascertained that Organizational Structure, Management accounting and accountants, integration of business intelligence, Performance measurement of management decisions, cost accounting, data analysis, reporting, budgeting etc. are good support for measuring the relationship between ERP and Management Accounting while factors like corporate size, strategy, cloud computing etc. are low support factors with respect to it. As far as methods of management accounting are concerned, most of the papers under review suggested that all the method so recognized under table 2, are equally been taken under post ERP systems for management accounting and control.

\section{How Does Enterprise Resourse Planning And Management Accounting Are Interrelated:-}

Enterprise resource planning is one of the software tools which make an organization's data management easy and handy. An organization with too many departments each more or less linked to finance and accounting department makes it difficult to extract data for managerial decision making in manual accounting systems. With introduction of ERP large industries like Big Organizations like Reliance, Essar, Tata, L \& T, Coca Cola, Adani, Bombay Dyeing, Amul Birla etc. which are widely spread all over the globe and has offices/ plants everywhere has got a benefit of easy data access with click of a button. ERP helps a management accountant to make decision on the basis of MIS data which is available on his table through software popularly known as ERP.

\section{The relationship between management accounting and ERP can be summaries on the following basis:-}

$>$ ERP implementations are huge and are time consuming. If an ERP implementation takes more time than its estimated one, it becomes costly and has a negative impact on management decision making.

$>$ ERP can give all the past data but cannot give future data to make a $100 \%$ accurate decision on the basis of it. Budgets prepared on ERP are based on historical data. This cannot be considered accurate when it comes to non-accounting factors influencing managerial decision.

$>$ For Activity based costing, customer satisfaction survey, non-financial key performance indicators etc. kinds of management accounting processes only ERP cannot suffice the requirement of decision making. It needs human intervention (That of management accountant) and outside data (That of customers or competitors act) to make decisions. 
$>$ ERP like SAP which is very user's friendly and can be implemented with minimal customization is widely accepted by LE's. But for SME's, an ERP like SAP is more costly and implementing any other cheaper ERP makes it very difficult to extract managerial accounting data for the purpose of decision making.

$>$ First time adaptability of any ERP into a manual accounting firm is very difficult. Getting a user's acceptance on ERP is an issue for vendors. At the same time from implementation to first positive use, there is a time lag which makes it difficult for management accountant to make decision and use an ERP.

$>$ With global competitive environment ERP has become a fashion rather than a necessity. Companies often implement ERP just because their competitors are doing so, without acknowledging their budgets and requirements. These kinds of implementations also hampers the quality of decision making in management accounting when an inappropriate software is implemented within organization to hamper day to day working.

\section{Research Methedology:-}

The purpose of this paper is to investigate the research done in the field of ERP and management accounting . For this, the database of established scientific management accounting journals and information system journals were investigated. The list of journals under the study was as follows:

\begin{tabular}{|c|c|}
\hline Accounting Journals & Information system journals \\
\hline $\begin{array}{l}\text { - } \text { Management Accounting Journal (MAJ) } \\
\text { - Journal of Management (JM) } \\
\text { - International Journal of Economic Science and } \\
\text { - } \text { applied research } \\
\text { Auditing and Accountability Journal. }\end{array}$ & $\begin{array}{l}\text { - International journal of accounting information } \\
\text { systems. } \\
\text { - Journal of Enterprise Information Management } \\
\text { - Journal of Information System \& Technology } \\
\text { Management }\end{array}$ \\
\hline
\end{tabular}

These journals are chosen for the purpose of extracting the review of literature also the methodologies and extract on account of inter-relation between ERP and Management accounting.

The method considered under the research was to recognize the most reviewed or analyzed methods for the purpose of determining relationship in ERP and Management accounting. Based on the literature review factors of testing the inter-relationship of ERP and management accounting were identified as Organizational structure, Management accounting and management accountant, business intelligence, performance of firm, cost accounting procedures, data analysis, reporting and budgeting.

Also, four management accounting techniques viz., Activity Based Costing (ABC), Balance Score Card (BSC), Target Costing (TC) and Life cycle costing (LC) were also identified to find implications of these management accounting practices in an ERP environment.

\section{Research design and Data Collection:-}

A five point likert scale questionnaire was developed to find users view on management accounting process in ERP environment. The questionnaire was sent to 70 managers / users of ERP in different type of manufacturing organizations have been given these questionnaires to be filled for the purpose of data analysis. 40 users /managers responded and on the basis of the data so collected multiple regression analysis was to analyses the data.

\section{Data Analysis and findings:-}

The questionnaire so received from the sources only 30 were considered for ANOVA .10 responses were rejected on the grounds of either not completely filled in or filled by a non-user. The data analysis was done with the help of ANOVA using excel from data analysis option.

The data collected was segregated and drafted in excel and the ANOVA was generated as follows:

Objective 1:- To find out the impact of ERP implementation on the organizations overall management accounting process

Multiple regression analysis was done for to check all the Management Accounting techniques relations to factors of performance evaluation in an ERP environment. The data gave following results. 


\begin{tabular}{|c|c|}
\hline \multicolumn{2}{|c|}{ Regression Statistics } \\
\hline Multiple R & 0.76 \\
\hline R Square & 0.57 \\
\hline Adjusted R Square & 0.50 \\
\hline Standard Error & 0.88 \\
\hline Observations & 29.00 \\
\hline
\end{tabular}

\begin{tabular}{|c|c|c|c|c|c|}
\hline ANOVA & & & & & \\
\hline & $d f$ & $S S$ & $M S$ & $F$ & Significance F \\
\hline Regression & 4 & 25.07 & 6.27 & 8.03 & 0.00 \\
\hline Residual & 24 & 18.73 & 0.78 & & \\
\hline Total & 28 & 43.79 & & & \\
\hline
\end{tabular}

\begin{tabular}{|l|l|l|l|l|l|l|l|l|}
\hline & $\begin{array}{l}\text { Coefficient } \\
s\end{array}$ & $\begin{array}{l}\text { Standard } \\
\text { Error }\end{array}$ & Stat & $\begin{array}{l}\text { P- } \\
\text { value }\end{array}$ & $\begin{array}{l}\text { Lower } \\
95 \%\end{array}$ & $\begin{array}{l}\text { Upper } \\
95 \%\end{array}$ & $\begin{array}{l}\text { Lower } \\
95.0 \%\end{array}$ & $\begin{array}{l}\text { Upper } \\
95.0 \%\end{array}$ \\
\hline $\begin{array}{l}\text { Intercep } \\
\mathrm{t}\end{array}$ & 0.618 & 0.495 & 1.248 & 0.224 & -0.404 & 1.641 & -0.404 & 1.641 \\
\hline ABC & 3.109 & 1.108 & 2.805 & 0.010 & 0.822 & 5.396 & 0.822 & 5.396 \\
\hline BSC & 2.000 & 0.883 & 2.264 & 0.033 & 0.177 & 3.823 & 0.177 & 3.823 \\
\hline TC & -3.301 & 1.284 & - & 0.017 & -5.950 & -0.651 & -5.950 & -0.651 \\
\hline LC & -1.192 & 0.629 & - & 0.070 & -2.489 & 0.106 & -2.489 & 0.106 \\
\hline
\end{tabular}

The P-value when more than 0.05 needs to be excluded from the list of independent variables (ABC, BSC etc.) . As $\mathrm{P}$ value 0.05 or greater says that the predicted value of the variable is as such it is insignificant for the analysis of the outcome. As lifecycle costing is the independent variable whose $\mathrm{P}$ - value is more than 0.05 , it means that the variable is insignificant for the purpose of analysis.

Checking on Significance of $\mathrm{f}$ which is coming to 0.000294188 shows that the variables so considered in the analysis is although below 0.05 but is significant for the analysis.

Looking at coefficient we can see again LC ( -1.191881919) is totally insignificant along with TC (3.300738007) which is in negative. This show that on the basis of data so collected the only significant management accounting practice post ERP adoption are ABC and BSC. This analysis can also change as the number of users are too less as compare to world ERP using organization.

Here on the basis of above analysis we partially accept $\mathrm{Ha}_{0}$ : ERP implementation has a positive impact on management accounting Processes.

\section{Objective 3:- To find the impact of Management processes on different factors of better performance in an ERP environment.}

Where, analysis of each management practice under study like ABC, BSC, TC and LC individually w.r.t the factors of performance evaluation gave another picture as:

Multi regression analysis of Activity costing (Dependent Variable) to Factors of performance evaluation (Independent variables)

\begin{tabular}{|c|c|}
\hline \multicolumn{2}{|c|}{ Regression Statistics } \\
\hline Multiple R & 0.774 \\
\hline R Square & 0.598 \\
\hline Adjusted R Square & 0.438 \\
\hline Standard Error & 1.068 \\
\hline Observations & 29.000 \\
\hline
\end{tabular}




\begin{tabular}{|c|c|c|c|c|c|}
\hline ANOVA & & & & & \\
\hline & $d f$ & $S S$ & $M S$ & $F$ & Significance F \\
\hline Regression & 8 & 34.01 & 4.25 & 3.73 & 0.01 \\
\hline Residual & 20 & 22.82 & 1.14 & & \\
\hline Total & 28 & 56.83 & & & \\
\hline
\end{tabular}

\begin{tabular}{|c|c|c|c|c|c|c|c|c|}
\hline & $\begin{array}{c}\text { Coefficie } \\
\text { nts }\end{array}$ & $\begin{array}{c}\text { Standard } \\
\text { Error }\end{array}$ & $t$ Stat & $\begin{array}{c}P- \\
\text { valu } \\
e\end{array}$ & $\begin{array}{c}\text { Lower } \\
95 \%\end{array}$ & $\begin{array}{c}\text { Upper } \\
95 \%\end{array}$ & $\begin{array}{c}\text { Lower } \\
95.0 \%\end{array}$ & $\begin{array}{c}\text { Upper } \\
95.0 \%\end{array}$ \\
\hline Intercept & -0.61 & 1.00 & -0.61 & 0.55 & -2.69 & 1.47 & -2.69 & 1.47 \\
\hline $\begin{array}{c}\text { Organizational } \\
\text { Structure }\end{array}$ & 0.20 & 0.19 & 1.05 & 0.30 & -0.20 & 0.60 & -0.20 & 0.60 \\
\hline MA & 0.14 & 0.21 & 0.68 & 0.50 & -0.30 & 0.59 & -0.30 & 0.59 \\
\hline BI & 0.13 & 0.22 & 0.59 & 0.56 & -0.33 & 0.60 & -0.33 & 0.60 \\
\hline Perf. Man & 0.36 & 0.18 & 1.99 & 0.06 & -0.02 & 0.73 & -0.02 & 0.73 \\
\hline Cost Acc & 0.07 & 0.16 & 0.41 & 0.69 & -0.27 & 0.40 & -0.27 & 0.40 \\
\hline Data Analysis & -0.26 & 0.18 & -1.42 & 0.17 & -0.64 & 0.12 & -0.64 & 0.12 \\
\hline Reporting & 0.06 & 0.16 & 0.38 & 0.70 & -0.27 & 0.39 & -0.27 & 0.39 \\
\hline Budgeting & 0.69 & 0.21 & 3.36 & 0.00 & 0.26 & 1.12 & 0.26 & 1.12 \\
\hline
\end{tabular}

Again when we check the analysis data, P-value of most of the variables except data analysis and performance management are more the n 0.05 i.e., totally insignificant. It shows that as far as $\mathrm{ABC}$ analysis is concerned, the performance of management accounting in post ERP companies is mostly likely to be depending on whether the organization is able to do better data analysis of the records in ERP.

A significance $f$ on the contrary shows that independent variables are significant and ABC in an ERP environment can be significant measure for the analysis.

Multi regression analysis of Balance Score card (Dependent Variable) to Factors of performance evaluation (Independent variables)

\begin{tabular}{|c|c|}
\hline \multicolumn{2}{|c|}{ Regression Statistics } \\
\hline Multiple R & 0.678 \\
\hline R Square & 0.460 \\
\hline Adjusted R Square & 0.244 \\
\hline Standard Error & 1.217 \\
\hline Observations & 29 \\
\hline
\end{tabular}

\begin{tabular}{|l|r|r|r|r|r|}
\hline ANOVA & & & & \\
\hline & $d f$ & $S S$ & $M S$ & F & Significance F \\
\hline Regression & 8 & 25.22 & 3.15 & 2.13 & 0.08 \\
\hline Residual & 20 & 29.60 & 1.48 & & \\
\hline Total & 28 & 54.83 & & & \\
\hline
\end{tabular}




\begin{tabular}{|c|c|c|c|c|c|c|c|c|}
\hline & $\begin{array}{c}\text { Coefficie } \\
\text { nts }\end{array}$ & $\begin{array}{c}\text { Standard } \\
\text { Error }\end{array}$ & t Stat & $\begin{array}{c}\text { P- } \\
\text { value }\end{array}$ & $\begin{array}{c}\text { Lower } \\
95 \%\end{array}$ & $\begin{array}{c}\text { Upper } \\
95 \%\end{array}$ & $\begin{array}{c}\text { Lower } \\
95.0 \%\end{array}$ & $\begin{array}{c}\text { Upper } \\
95.0 \%\end{array}$ \\
\hline Intercept & -0.07 & 1.14 & -0.06 & 0.95 & -2.44 & 2.30 & -2.44 & 2.30 \\
\hline $\begin{array}{c}\text { Organizational } \\
\text { Structure }\end{array}$ & 0.15 & 0.22 & 0.69 & 0.50 & -0.31 & 0.61 & -0.31 & 0.61 \\
\hline MA & 0.20 & 0.24 & 0.83 & 0.42 & -0.30 & 0.70 & -0.30 & 0.70 \\
\hline BI & 0.11 & 0.25 & 0.42 & 0.68 & -0.42 & 0.64 & -0.42 & 0.64 \\
\hline Perf. Man & 0.25 & 0.20 & 1.22 & 0.24 & -0.18 & 0.68 & -0.18 & 0.68 \\
\hline Cost Acc & 0.33 & 0.18 & 1.79 & 0.09 & -0.05 & 0.71 & -0.05 & 0.71 \\
\hline Data Analysis & -0.26 & 0.21 & -1.25 & 0.22 & -0.69 & 0.17 & -0.69 & 0.17 \\
\hline Reporting & 0.05 & 0.18 & 0.27 & 0.79 & -0.33 & 0.42 & -0.33 & 0.42 \\
\hline Budgeting & 0.42 & 0.23 & 1.78 & 0.09 & -0.07 & 0.91 & -0.07 & 0.91 \\
\hline
\end{tabular}

Looking at the $\mathrm{P}$ value many factors like Organizational structure, management accounting \& accountant, performance management, Cost accounting, data analysis and budgeting are significant factors for analysis of balance score card as a good practice in firms using ERP.

Multi regression analysis of Target Costing (Dependent Variable) to Factors of performance evaluation (Independent variables)

\begin{tabular}{|l|r|l|l|l|l|l|}
\hline \multicolumn{2}{|c|}{ Regression Statistics } & & & & \\
\hline Multiple R & 0.745746942 & & & & & \\
\hline R Square & 0.556138501 & & & & & \\
\hline Adjusted R Square & 0.378593901 & & & & & \\
\hline Standard Error & 1.023929427 & & & & & \\
\hline Observations & 29 & & & & & \\
\hline \hline ANOVA & $d f$ & & & & & \\
\hline & 8 & 26.27274987 & 3.284093733 & 3.13238759 & 0.018228166 & \\
\hline Regression & 20 & 20.96862945 & 1.048431472 & & & \\
\hline Residual & 28 & 47.24137931 & & & & \\
\hline Total & & & & & & \\
\hline
\end{tabular}

\begin{tabular}{|c|c|c|c|c|c|c|c|c|}
\hline & $\begin{array}{c}\text { Coefficie } \\
\text { nts }\end{array}$ & $\begin{array}{c}\text { Standard } \\
\text { Error }\end{array}$ & t Stat & $\begin{array}{c}\text { P- } \\
\text { value }\end{array}$ & $\begin{array}{c}\text { Lower } \\
95 \%\end{array}$ & $\begin{array}{c}\text { Upper } \\
95 \%\end{array}$ & $\begin{array}{c}\text { Lower } \\
95.0 \%\end{array}$ & $\begin{array}{c}\text { Upper } \\
95.0 \%\end{array}$ \\
\hline Intercept & -0.34 & 0.96 & -0.36 & 0.72 & -2.34 & 1.65 & -2.34 & 1.65 \\
\hline $\begin{array}{c}\text { Organizational } \\
\text { Structure }\end{array}$ & 0.14 & 0.18 & 0.75 & 0.46 & -0.25 & 0.52 & -0.25 & 0.52 \\
\hline MA & 0.12 & 0.20 & 0.58 & 0.57 & -0.30 & 0.54 & -0.30 & 0.54 \\
\hline BI & 0.15 & 0.21 & 0.70 & 0.49 & -0.30 & 0.59 & -0.30 & 0.59 \\
\hline Perf. Man & 0.18 & 0.17 & 1.04 & 0.31 & -0.18 & 0.54 & -0.18 & 0.54 \\
\hline Cost Acc & 0.22 & 0.15 & 1.46 & 0.16 & -0.10 & 0.55 & -0.10 & 0.55 \\
\hline Data Analysis & -0.06 & 0.17 & -0.37 & 0.71 & -0.43 & 0.30 & -0.43 & 0.30 \\
\hline Reporting & 0.07 & 0.15 & 0.48 & 0.63 & -0.24 & 0.39 & -0.24 & 0.39 \\
\hline Budgeting & 0.53 & 0.20 & 2.70 & 0.01 & 0.12 & 0.94 & 0.12 & 0.94 \\
\hline
\end{tabular}

Accept for budgeting no other factors shows a significant $\mathrm{P}$ value for the purpose of analyzing target costing as a significant dependent variable on the independent variables for the purpose of analysis of variance. A 0.018228166 of "Significance f" make the analysis significant for the purpose of performance evaluation.

Multi regression analysis of Lifecycle Costing (Dependent Variable) to Factors of performance evaluation (Independent variables) 


\begin{tabular}{|c|c|c|c|c|c|c|c|c|c|}
\hline \multicolumn{2}{|c|}{ Regression Statistics } & & & & & & & & \\
\hline Multiple R & 0.683918904 & & & & & & & & \\
\hline R Square & 0.467745067 & & & & & & & & \\
\hline $\begin{array}{l}\text { Adjusted R } \\
\text { Square }\end{array}$ & 0.254843094 & & & & & & & & \\
\hline Standard Error & 1.229771586 & & & & & & & & \\
\hline Observations & 29 & & & & & & & & \\
\hline \multicolumn{8}{|l|}{ ANOVA } & & \\
\hline & $d f$ & $S S$ & $M S$ & & $F$ & \multirow{2}{*}{\multicolumn{2}{|c|}{$\begin{array}{r}\text { Significance } F \\
0.073398625\end{array}$}} & & \\
\hline Regression & 8 & $\begin{array}{r}26.580823 \\
13 \\
\end{array}$ & 3.3226 & & $\begin{array}{r}2.1969 \\
97334 \\
\end{array}$ & & & & \\
\hline Residual & 20 & $\begin{array}{r}30.246763 \\
07\end{array}$ & \multicolumn{2}{|c|}{$\begin{array}{r}1.5123381 \\
54\end{array}$} & & & & & \\
\hline \multirow[t]{2}{*}{ Total } & 28 & $\begin{array}{r}56.827586 \\
21 \\
\end{array}$ & & & & & & & \\
\hline & $\begin{array}{c}\text { Coefficient } \\
s \\
\end{array}$ & $\begin{array}{l}\text { Standard } \\
\text { Error }\end{array}$ & $t$ Stat & & alue & $\begin{array}{l}\text { Lower } \\
95 \%\end{array}$ & $\begin{array}{l}\text { Upper } \\
95 \%\end{array}$ & $\begin{array}{l}\text { Lower } \\
95.0 \%\end{array}$ & $\begin{array}{l}\text { Upper } \\
95.0 \%\end{array}$ \\
\hline Intercept & -0.71 & 1.15 & -0.62 & & 0.54 & -3.11 & 1.68 & -3.11 & 1.68 \\
\hline $\begin{array}{l}\text { Organizational } \\
\text { Structure }\end{array}$ & 0.36 & 0.22 & 1.63 & & 0.12 & -0.10 & 0.82 & -0.10 & 0.82 \\
\hline MA & 0.41 & 0.24 & 1.69 & & 0.11 & -0.10 & 0.92 & -0.10 & 0.92 \\
\hline BI & 0.15 & 0.26 & 0.60 & & 0.56 & -0.38 & 0.69 & -0.38 & 0.69 \\
\hline Perf. Man & 0.35 & 0.21 & 1.67 & & 0.11 & -0.09 & 0.78 & -0.09 & 0.78 \\
\hline Cost Acc & 0.28 & 0.18 & 1.51 & & 0.15 & -0.11 & 0.67 & -0.11 & 0.67 \\
\hline Data Analysis & -0.15 & 0.21 & -0.73 & & 0.47 & -0.59 & 0.28 & -0.59 & 0.28 \\
\hline Reporting & -0.09 & 0.18 & -0.49 & & 0.63 & -0.47 & 0.29 & -0.47 & 0.29 \\
\hline Budgeting & 0.35 & 0.24 & 1.46 & & 0.16 & -0.15 & 0.84 & -0.15 & 0.84 \\
\hline
\end{tabular}

A Significance F 0.073398625 shows that again the dependent variable has a significant relationship with the independent variables. Although most of the factors again have a P-value which is below 0.05 recommending that target costing is being taken care in ERP environment as a management accounting practice.

On the basis of above we can again accept $\mathrm{Hb}_{0}$ : As out of four three of the Management processes can be considered as significant in ERP environment on the basis of factors of performance.

Objective 2:- To find whether management accounting processes are related to size of organization in an ERP environment.

\begin{tabular}{|l|r|l|l|l|l|l|}
\hline \multicolumn{2}{|c|}{ Regression Statistics } & & & & \\
\hline Multiple R & 0.2816007 & & & & & \\
\hline R Square & 0.079298954 & & & & & \\
\hline Adjusted R Square & -0.07415122 & & & & & \\
\hline Standard Error & 1.475603287 & & & & & \\
\hline Observations & 29 & & & & & \\
\hline \hline ANOVA & $d f$ & & & & & \\
\hline & 4 & 4.500899256 & 1.125224814 & 0.516773307 & 0.724121854 & \\
\hline Regression & 24 & 52.25772143 & 2.17740506 & & & \\
\hline Residual & 28 & 56.75862069 & & & & \\
\hline Total & & & & & & \\
\hline
\end{tabular}




\begin{tabular}{|c|c|c|c|c|c|c|c|c|}
\hline & $\begin{array}{c}\text { Coefficie } \\
\text { nts }\end{array}$ & $\begin{array}{c}\text { Standard } \\
\text { Error }\end{array}$ & t Stat & $\begin{array}{c}P- \\
\text { value }\end{array}$ & $\begin{array}{c}\text { Lower } \\
95 \%\end{array}$ & $\begin{array}{c}\text { Upper } \\
95 \%\end{array}$ & $\begin{array}{c}\text { Lower } \\
95.0 \%\end{array}$ & $\begin{array}{c}\text { Upper } \\
95.0 \%\end{array}$ \\
\hline Intercept & 3.72 & 0.83 & 4.49 & 0.00 & 2.01 & 5.44 & 2.01 & 5.44 \\
\hline ABC & -0.09 & 0.33 & -0.28 & 0.78 & -0.78 & 0.59 & -0.78 & 0.59 \\
\hline BSC & 0.14 & 0.35 & 0.39 & 0.70 & -0.59 & 0.87 & -0.59 & 0.87 \\
\hline TC & 0.01 & 0.41 & 0.02 & 0.98 & -0.85 & 0.87 & -0.85 & 0.87 \\
\hline LC & -0.31 & 0.37 & -0.83 & 0.41 & -1.08 & 0.46 & -1.08 & 0.46 \\
\hline
\end{tabular}

Looking at the regression analysis of the data on the basis of four practice of management accounting a standard error of 1.47 and a Significance " $f$ " of 0.724121854 (which is above 0.05) shows that the size of firm is not being significantly related to management practice. Also the P-value of all the independent variables is more than 0.05 which signifies that none of the factor has any significant relationship with type of organization and hence we reject the null hypothesis and select the alternative hypothesis.

$\mathrm{Hb}_{1}$ : There is no relation between management accounting processes to size of organization in an ERP environment.

\section{Conclusion and Recommendations:-}

This small empirical study on ERP and management accounting has given an area for further research as to how implementation of ERP has an impact on management decision making. So far from the empirical study it can be concluded that ERP when implemented gives a very positive impact on management accounting as to decision making in the field of production, make or buy decisions, BOM, supply chain management, outsourcing, etc. ERP's like SAP, PeopleSoft, MSD and others needs to be studied in detail industry wise to comment upon the acceptance as to management accounting. Although ERP has gain rapid advancement in last decade, it is still an unread book for researchers with the prospective of end users eyes. Thus, although we accept out hypothesis as to "there is a positive relationship between ERP implementations and Management accounting", but at the same time we also had restricted this paper to a small group of users/ managers and the research analysis and outcomes can come to total contradiction when it comes to the huge sample in different types of companies using ERP. As this research is primary investigation opening up the doors for a broader frontier, it is highly recommended that before coming to any conclusion factors like type of ERP for MA processes, many other kind of management practices and large pool of end users view should be considered for the higher end research.

\section{Bibliography:-}

1. On the Interface between Management Accounting and Modern Information Technology -. (2007, May). Markus GRANLUND. Turku, Finland .

2. Altekar, R. V. (2009). Enterprisewide Resource Planning. Hyderabad: PHI.

3. Arnold, V. (2006). Behavioral research opportunities: understanding the impact of enterprise. International Journal of Accounting Information Systems, 7-17.

4. Baxendale, S. a. (2003). What ERP can offer ABC”, Strategic Finance. Strategic Finance.

5. Drury, C. (2008). Management and cost accounting. London: Gengage Learning.

6. Gaertner, B., \& Feldbauer-Durstmueller, B. (2012). ERP-SYSTEMS AND MANAGEMENT ACCOUNTING: A LITERATURE REVIEW AND FUTURE RESEARCH. An Enterprise Odyssey. International Conference Proceedings (pp. 638-652). Zagreb: University of Zagreb, Faculty of Economics and Business.

7. Granlund, M. a. (1998). "Towards increasing business orientation: Finnish management accountants in a changing cultural context. Management Accounting reserach, pp. 185-211.

8. Granlund, M. a. (2002). Moderate impact of ERPS on management accounting:. Management Accounting Research, pp. 299-321.

9. Gullkvist, B. M. (Sept, 2013). Drivers of Change in Management Accounting Practices in an ERP Environment. International Journal of Economic Sciences and Applied Research 6 (2): , 149-174.

10. Holtzman, Y. (2004). The transformation of the accounting profession in the United States: from information processing to strategic business advising. Journal of Management, 949-961.

11. Hyvonen, T. (2003). Management Accounting and Information System: ERP vs Bob. European Accounting Review, 155-173. Lowe, A. (2004). "Postsocial relations: toward a performative view of accounting knowledge. Accounting, Auditing \& Accountability Journal, 604-628. 
12. Malinic, S., \& Todorovic, M. (2012, Sep). HOW DOES MANAGEMENT ACCOUNTING CHANGE UNDER THE INFLUENCE OF ERP? Ekonomska Istrazivanja. Pula: Sveuciliste Jurja Dobrile u Puli, Odjel za Ekonomiju i Turizam "Dr. Mijo Mirkovic".

13. Nikolaos Vakalfotis, J. B. (July 2011). A Literature Review on the Impact of Enterprise Systems on Management Accounting. 8th International Conference on Enterprise Systems, Accounting and Logistics (ICESAL), (p. 27). Thassos Island,.

14. Rohde, A. R. (2006). Enterprise resource planning systems, strategic enterprise management systems and management accounting. Journal of enterprise information management, 50-66.

15. Ronald W Hilton, G. R. (2008). Managerial Accounting. Tata McGrwa-Hill.

16. Sánchez-Rodríguez, C. P., \& Spraakman, G. (2012). ERP systems and management accounting: a multiple case study. Qualitative Research in Accounting and Management, 398-414.

17. Sangster, A., Leech, S. A., \& Grabski, S. (2009). ERP IMPLEMENTATIONS AND THEIR IMPACT UPON MANAGEMENT ACCOUNTANTS . Journal of Information Systems and Technology Management : JISTEM, 125-141.

18. Scapens, R. a. (2003). ERP systems and management accounting change: opportunities or impacts? A research note. European Accounting Review.
Abbreviations:-
ABC : Activity Based Costing
BSC: Balance Score Card
LC: Lifecycle Costing
TC: Target Costing
ERP: Enterprise Resource planning
MA: Management Accounting. 